5. Livshits, P. (1939). Stage makeup. Leningrad; Moscow: Iskusstvo.

6. Meyson, L. (2014). Makeup for Ageless Beauty: More than 40 Colorful, Creative Looks for Women at 40 and Over. Moscow: Eksmo.

7. Melnik, M. 'Style: concept and specificity of manifestation in fashion', [online] Available at: http://vuzlib.com/content/view/1560/62/. [Accessed 19 April 2018].

8. Pelageychenko, M., Filenko, O. From the history of makeup. Makeup as a method of correction of face shape and features, [online] Available at: https://mozok.click/1876-z-storyi-makyazhu-makyazh-yak-korekcya-formi-ta-risoblichchya.html [Accessed 19 April 2018].

9. Raugul, R. (1947). Makeup. Moscow: Iskusstvo

10. Stanislavsky, K. (1954). My life in art. Vol. 11. Moscow: Vagrius.

Velflin, G. (1994). Basic concepts of the history of art: The problem of the evolution of style in the new art. St. Petersburg: MIFRIL.

(C) Момчилова А. Г., 2018

УДК $76+655.533+391]: 316.77(06)$

Удріс-Бородавко Наталя Сергіївна кандидат соиіологічних наук, доцент, завідувач кафедри графічного дизайну, Київський національний університет культури і мистецтв, Київ, Україна udris.nata@ukr.net

\title{
КОЛАЖ У ФОРМУВАННІ НАЦІОНАЛЬНОЇ МОДЕЛІ ГРАФІЧНОГО ДИЗАЙНУ УКРАЇНИ ХХІ СТОЛІТТЯ
}

Мета роботи. У сучасній візуальній комунікації колаж як вид графічного дизайну та колажування як прийом візуалізації активно поширюється, а теоретичного науково обгрунтованого підгрунтя та узагальнення не сформовано. Стаття присвячена аналізу колажу як виду графічного дизайну та виявленню тих його аспектів, що формують унікальність українського графічного дизайну на світовому рівні. Методи дослідження полягають у застосуванні емпіричного методу, аналізу, порівняння та узагальнення. Зазначений методологічний підхід дозволяє вивчати тенденції використання колажу в продукції графічного дизайну останніх 5-6 років, спостерігати за динамікою прийому колажування в проектах, узагальнити особливості та сформулювати характерні ознаки графічного дизайн-колажу. Наукова новизна результатів полягає в уточненні поняття «колаж» та його особливості в сфері графічного дизайну XXI ст., стислому узагальненні історичних етапів формування культури колажу в графічному дизайні Європи та України. Вперше 
сформульовано ознаки графічного дизайн-колажу, які водночас $є$ й критеріями визначення рівня професійності того чи іншого проекту. Висновки. На основі аналізу реалізованих проектів українських дизайнерів сформульовано такі ознаки графічного дизайн-колажу як ефект рукотворності, емоційність, багатозначність, креативність, візуальна ідентифікація графічними елементами етнічного походження. Це доводить, що колаж є такою візуальною формою, яка сприяє ефективному формуванню національної моделі графічного дизайну в Україні, а прийом колажування треба вивчати та вводити навчальним модулем в систему дизайн-освіти.

Ключові слова: колаж, графічний дизайн, фотоколаж, національна модель.

Удрис-Бородавко Наталья Сергеевна, дочент кафедры графического дизайна, Киевский начиональный университет культуры и искусств, Киев, Украина

Коллаж в формировании национальной модели графического дизайна Украины XXI века

Цель работы. В современной визуальной коммуникации коллаж как вид графического дизайна и коллажирование как прием визуализации активно распространяется, а теоретического научно обоснованного основания и обобщения не сформировано. Статья посвящена анализу коллажа как вида графического дизайна и выявлению тех его аспектов, которые формируют уникальность украинского графического дизайна на мировом уровне. Методы исследования заключается в применении эмпирического метода, анализа, сравнения и обобщения. Указанный методологический подход позволяет изучать тенденции использования коллажа в продукции графического дизайна последних 5-6 лет, наблюдать за динамикой приема коллажирования в проектах, обобщить особенности и сформулировать характерные признаки графического дизайн-коллажа. Научная новизна заключается в уточнении понятия «коллаж» и его особенности в сфере графического дизайна XXI в., сжатом обобщении исторических этапов формирования культуры коллажа в графическом дизайне Европы и Украины. Впервые сформулированы признаки графического дизайн-коллажа, которые одновременно являются и критериями определения уровня профессионализма того или иного проекта. Выводы. На основе анализа реализованных проектов украинских дизайнеров сформулированы такие признаки графического дизайна коллажа, как эффект рукотворности, эмоциональность, многозначность, креативность, визуальная идентификация графическими элементами этнического происхождения. Это доказывает, что коллаж является такой визуальной форме, способствует эффективному формированию национальной модели графического дизайна в Украине, а прием коллажирования надо изучать и вводить учебным модулем в систему дизайн-образования.

Ключевые слова: коллаж, графический дизайн, фотоколлаж, национальная модель. 
Udris-Borodavko Natalia, PhD in Sociology, associate professor, head of Graphic Design Department, Kyiv National University of Culture and Arts, Kyiv, Ukraine Collage in the formation of the national model of graphic design of 21st century Ukraine

The purpose of the article. In modern visual communication, collage as a kind of graphic design and collaging as a means of visualization are actively promoted, but the theoretical scientifically substantiated background and generalization were not formed. The article is devoted to the analysis of collage as a kind of graphic design and identification of the aspects shaping the uniqueness of Ukrainian graphic design in the world. The research methodology consisted in applying the empirical method, analysis, comparison and generalization. This methodological approach allowed for studying the tendencies of using collage in products of graphic design of the last 5-6 years, observing the dynamics of using the technique of collaging in projects, generalizing the peculiarities and defining the characteristics of graphic design-collage. The scientific novelty of the work lies in clarifying the concept of collage and its features in the field of graphic design of the 21 st century, as well as brief generalization of the historical stages of the formation of collage culture in graphic design in Europe and Ukraine. Features of graphic designcollage, which are also criteria for determining the level of professionalism of a project, were defined for the first time. Conclusions. Based on the analysis of implemented projects of Ukrainian designers, the following features of graphic design collage were established: the hand-made effect, emotionality, polysemy, creativity, and visual identification by graphic elements of ethnic origin. This proves that collage is a visual form that contributes to the effective formation of the national model of graphic design in Ukraine, and the technique of collaging should be studied and introduced as an academic module into the system of design education.

Key words: collage, graphic design, photo collage, national model.

Вступ. У графічному дизайні України протягом останніх 5-6-ти років набув популярності колаж як засіб візуалізації ідеї. Колаж як вид візуальних мистецтв бере свій початок з 1912 р. У результаті свого стрімкого поширення та розмаїття інтерпретацій, в другій пол. $\mathrm{XX}$ ст. колаж був об'єктом мистецтвознавчих досліджень, хоча й не таким популярним, як ін. види мистецтв. В українських наукових статтях, присвячених зазначеній темі, увага авторів зосереджена переважно на аспектах об'ємних колажів як творів образотворчого мистецтва та об'єктів арт-дизайну в контексті елементів декорування інтер'єрів. Нас же цікавить колаж у графічному дизайні, зокрема тенденції його застосування саме українськими дизайнерами та ілюстраторами. Обмежена кількість упорядкованих аналітичних матеріалів 3 цієї теми обумовлює актуальність статті. 
Мета статті - проаналізувати колаж як вид графічного дизайну та виявити ті його аспекти, що формують унікальність українського графічного дизайну на світовому рівні. Завдання дослідження. 3'ясувати значення поняття «колаж» та його особливості в сфері графічного дизайну XXI ст.; дослідження історичних етапів формування культури колажу в графічному дизайні Європи та України; аналіз проектів українських дизайнерів на основі колажу; виявлення особливостей дизайн-колажів відповідно до національної моделі графічного дизайну в Україні.

Аналіз останніх досліджень і публікацій. Наше дослідження грунтується на роботах в сфері теорії формування національної моделі українського дизайну (автори В. Даниленко, В. Косів, С. Антонович, А. Руденченко, А. Бровченко, Р. Силко, С. Прищенко та ін.). Аналіз робіт зазначених авторів та визначення глобалізаційних i національних векторів розвитку графічного дизайну в Україні робить Л. Триноженко, О. Гладун [2]. Крім досліджень графічного дизайну, підгрунтям нашої статі були наукові розвідки в галузі мистецтвознавчого й культурологічного аналізу колажів як виду мистецтва та прийому. Наукові роботи, дотичні до зазначеної теми статті присвячені переважно двом аспектам: історичному огляду творчості художників і дизайнерів, які активно працювали в цій техніці та аналізу колажів як носіїв концептуальних поглядів, настроїв, громадської активності діячів культури і мистецтва на певному етапі розвитку суспільстві. На думку українського вченого Г. Колісниченка, проблема наукового вивчення колажу пов'язана 3 тим, що в різних напрямках мистецтва колаж виконував різні пластичні завдання. Колаж має складну структуру та широкі виразні можливості, він може бути класифікований за часом створення, техніками, матеріалами, прийомами виконання та композиціями, але його потрібно вивчати в царині тієї художньої парадигми, у якій він зростав та еволюціонував [6, с. 155]. Дослідниця М. Решетова аналізує особливості підходів до створення колажів представниками дадаїзму, кубізму, сюрреалізму [8, с. 65-67]. Вона приходить висновку, що протягом ХХ ст. відбулися суттєві зміни в розумінні колажу та застосування його для візуалізації ідей. У контексті версії постмодернізму XXI ст. колаж демонструє цінність фрагмента реальності. У XXI ст. колаж інтерпретується не як «поєднання різних за статусом і значенням елементів, а як символ сучасної епохи» [8, с. 69]. I. Педан вважає, що популярність колажу в XXI ст. є проявом цитатного мислення, сформованого за часів постмодернізму, оскільки цитатність є одним з основних його характеристик. Принцип інтертекстуальності, що $є$ провідним у теорії структуралізму та поструктуралізму, закладено в основу сучасної творчості. «Індивідуальний твір перестає існувати, оскільки новий твір складається в культурній тканині 3 образів, що вже існують» [7, с. 45].

Узагальнення вивчених робіт обраної теми дозволяє зробити висновок, що колаж як тема наукових розвідок розробляється здебільшого в напрямах історії колажу як виду образотворчого мистецтва, культурології в контексті відповідності певному етапу розвитку суспільної думки та світогляду митців, 
а також використанню напівоб'ємних колажів з різних об’єктів в арт-дизайні та оформленні інтер'єрів. Наукові роботи, де висвітлено колаж як складову саме графічного дизайну, сформульовано теоретичні основи та методики створення графічних дизайн-колажів, а також місце в контексті формування української моделі графічного дизайну практично відсутні. Лише в обмежених інтернетресурсах можна знайти короткі оглядові описи та інтерв'ю $з$ авторами окремих проектів. Спостерігається певний дисонанс: в практичній сфері колаж як вид графічного дизайну та колажування як прийом візуалізації активно поширюється, a теоретичного науково обгрунтованого підгрунтя та узагальнення не сформовано. Це створює проблемну ситуацію. 3 метою часткового вирішення цієї проблеми проведено дослідження в цій статті.

Виклад основного матеріалу. Поняття «колаж» походить від французького collage - приклеювання, наклейка. Це техніка та вид образотворчого мистецтва, які полягають у створенні кольорових або графічних творів шляхом наклеювання на будь-яку основу матеріалів, різних за кольором і фактурою (тканина, мотузка, мереживо, шкіра, намисто, дерево, кора, фольга, метал та ін). На відміну від аплікації, колаж застосовується для об'ємних елементів у композиції, причому як цілих об’єктів, так і фрагментів посуду, спортивного інвентарю, годин, монет, платівок, взуття, рукавичок, віял, капелюхів тощо [4]. У графічному дизайні першою варіацією колажу був фотоколаж (1920-1930ті рр.), який можна трактувати як комбінування графічних та фотографічних матеріалів у незвичних ракурсах та поєднаннях. У сучасній професійній термінології найчастіше використовується такий варіант назви як «діджитал-колаж». У перекладі з англійської «digital» означає «цифровий», тобто створений за допомогою нових цифрових технологій, зокрема комп'ютера та графічних редакторів. Оскільки проекти графічного дизайну створюються саме цифровим методом, використання такої назви $\epsilon$ цілком природним. Український варіант може мати такий дослівний переклад як «цифровий» або «електронний» колаж.

Сучасний графічний дизайн-колаж сягає корінням в експерименти «предметного» колажу та аплікації. У мистецтвознавстві $є$ усталена дата народження мистецтва колажу, і більшість дослідників вважає, що саме як мистецький прийом він був закладений в 1912 р., коли П. Пікассо створив картину «Натюрморт із плетеним стільцем». Паралельно 3 Пікассо працював французький художник-кубіст Ж. Брак, який використовував оригінальний прийом наклеювання на картон смуг пофарбованого паперу. У наступне десятиліття колаж посідає помітне місце в творчості А. Матісса. Його аплікативні роботи 3 кольоровим папером, який художник особисто пофарбував, є спрощеними формами та максимально наближені до дизайну плакату. У 1920-1930рр. до колажу звертались представники різних художніх течій: кубісти - Х. Гріс, О. Архіпенко; футуристи - К. Карра, Дж. Северіні, В. Хлебніков, дадаїсти - К. Швіттерс, Х. Арп, художники українського конструктивізму - Д. Бурлюк, Б. Косарев, В. Срмілов, А. Петрицький та багато ін. 
Авторство фотоколажу, який сьогодні $є$ основою сучасного діджиталколажу, належить берлінській групі графіків «Dada». Дадаїсти створювали фотомонтажні ілюстрації для різних публікацій та видань, пропагандистські плакати і маніфести, спрямовані переважно проти нацизму. Вагомим внеском у розвиток графічного дизайн-колажу були роботи дадаїстів Дж. Хартфілда та Р. Хаусмана. Джон Хартфілд виробив свій особливий стиль фотомонтажу, в основі якого було поєднання художньої фотографії, графічного рисунку й тексту. Художній мінімалізм, технічність, лаконічність і змістовна спрямованість на соціальну загостреність та орієнтована на політичну сатиру [10]. Колажі Рауля Хаусмана також наповнені експериментами в поєднанні з вирізаних із газет світлин, написів, на перший погляд хаотичних та алогічних поєднань частин різних предметів. Такі уламки реальності водночас $\epsilon$ гармонічними композиціями, що свідчить про високий рівень професійності автора. Колажі Р. Хаусмана відкрили ще одну художньо-образну особливість цього виду графічного дизайну - гротескність [1].

Активний розвиток фотомонтажу й фотоколажу відбувся в школі дизайну Баухауз. Завдяки використанню великих геометричних форм і техніки, роботи з фотоматеріалом, представники цієї школи були винахідниками нової виразності. Одним з ідеологів фотомонтажу був угорський художник викладач Баухауз Л. Мохой-Надь. Основною концепцією його обкладинок і плакатів було поєднання фото зі шрифтом, а також оригінальні через свою технічну випадковість фотографії. Автор вважав, що світлина не повинна точно імітувати реальність, натомість популяризував фотограми - неімітовану безкамерну фотографію за допомогою світлочуттєвого порошка, основна виразність якої - неочікуваність результата і випадковість.

В Україні у 1920-х рр. техніка колажу ефективно впроваджувалась художниками театрально-декораційного мистецтва: О. Хвостенко-Хвостов та O. Екстер, які залишили неабияку спадщину технічних прийомів та використання рогожи, мотузки, заліза, скла, синтетичних матеріалів тощо. У сфері графічного дизайн-колажу вагомий внесок зроблено художниками кіноплакату доби конструктивізму (1920-1930-ті pp.) К. Болотовим, А. Бондаровичем, М. Длугачем, М. Івасюком, Ю. Кордишем, І. Літинським, С. Менделем, А. Мартиновим, А. Фіногеновим та ін. [2]. Динамічні композиції, різномасштабність зображених елементів, поєднання фігур у різних ракурсах, імітація напівоб'єму в зображеннях та пласкі однорідні площини - все це свідчить про колажне мислення українських художників, які працювали відповідно до сучасних їм мистецьких тенденцій.

Наприкінці 1930-х рр. інтерес до колажу знизився, що, насамперед, обумовлено диктатом політичних сил в Німеччині, Італії та колишньому СРСР. Проте в 1950-х рр. спалахнув 3 новою силою. Це пов'язано 3 мистецькою течією «поп-арт», яка з'явилась на Заході. Природно, колажі того часу відображають дух поп-арту, настрої та смаки, що були поширені в ті роки. Одним з основних художніх прийомів візуалізації ідеї був і колаж в творчості постмодернізму. Митці й дизайнери цієї доби надають перевагу колажності 
практично в усіх формах культури - стильовій еклектичності й комбінаториці в архітектурі, моді, кинематографі, рекламі. І. Педан, спираючись на дослідження інших авторів, пише, що постмодерністському колажу притаманний відхід від традиційних прийомів візуалізації, тяжіння до асоціативних композицій і абстрактного мислення, візуалізація філософсько-світоглядних позицій [6, с. 46].

3 розвитком технічного прогресу та появою потужних комп'ютерів колажування як мистецький прийом отримав «нове дихання» вже в XXI ст. у вигляді комп'ютерного колажу, що свідчить про його життєздатність та особливість. Сьогодні цей прийом має свою специфіку. У сучасному мистецькому просторі колаж отримав одну 3 провідних ролей і невід'ємне значення в сучасній образотворчій культурі. У мистецтві останніх років колаж постає в формі «вибуху» як механізм нового прочитання значень, що були структуровані до нього. На нашу думку, окрім зазначеного, популярність колажу у другому десятилітті XXI ст., обумовлена проявом «кліпового» мислення, про яке пишуть культурологи і психологи останні 10-15 років.

В Україні протягом останніх 5-6 років колаж набуває популярності. Українські графічні дизайнери застосовують колаж у рекламних кампаніях комерційних та культурних брендів, в оформленні книг та просто в мистецьких творах. Найпотужнішими й затребуваними сьогодні колажистами в Україні є брати Василь та Іван Костенки, які працюють під брендом «Braty». У 2016 р. поціновувачі мали змогу насолоджуватись рекламно-іміджевим проектом «Класики в моді» для торговельного бренду «Всі. Свої». Прекрасна ідея, креатив якої полягає і в назві, й у візуалізації. Можемо зазначити, що проект побудовано на прийомі «оксюморон», тобто поєднанні непоєднаного - людиниобразу, яка була важливою постаттю культурного минулого України та модного образу, який символізує XXI ст. Не менш цікавими проектами є серії плакатів «The Kievianer» та «Ukraine», якими вони презентували Україну на тижні української культури у Парижі навесні 2017 р. У плакатах поєднані елементи сучасної та історичної архітектури, фрагменти рослинного і тваринного світу, скульптура, пейзажі, персонажі, елементи продукції народних ремесел тощо. Використання монохромних старовинних портретних світлин наших пращурів та їхнє гармонійне поєднання 3 сучасними знімками створюють емоційне підгрунтя від споглядання та відчуття зв'язку поколінь. Серед ін. проектів цих дизайнерів вагомими $є$ рекламна кампанія для ТМ «Інтертоп», культурномистецького заходу «Гогольфест» та ін.

Характерна колажева візуалізація притаманна ілюстрованим виданням, створеним дизайнерами Романою Романишин та Андрієм Лєсівим (творча майстерня «Аграфка»), серед яких найвідомішими є «Андрій Шептицький» та «Іван Франко». Вони поєднують фрагменти старовинних світлин, авторські естампи та графічне доповнення, щоб створити дотепні образи та композиції титульних сторінок для книжкових видань.

Також вагомою для українського дизайн-колажу є творчість ілюстраторки Поліни Дорошенко. Найяскравіша ії робота - ілюстрації та макет книги «Лісова пісня». Ілюстрації та плакати авторки побудовані лише на графічних малюнках, 
але поєднання колірних та чорно-білих фрагментів різних за розміром та ракурсами предметів вирізняють їі роботи серед інших.

Узагальнюючи практичний досвід успішних дизайнерів можемо узагальнити ознаки графічного дизайн-колажу, які водночас $є$ i критеріями визначення рівня професійності того чи ін. проекту:

1. Експериментування з сенсами і значеннями

1.1. Цитатність.

1.2. Абсурдність.

1.3. Асоціативність.

1.4. Фрагментарність.

2. Експериментування з візуальними формами і техніками

2.1. Гротескність.

2.2. Стильова еклектика.

2.3. Фрагментарність.

2.4. Поєднання фотозображень, графічних елементів та акцидентних написів.

3. Динамічність композиції.

3.1. Порушення співвідношень реальних пропорцій зображених об'єктів.

3.2. Незвичність ракурсів.

3.3. Наявність візуальної домінанти.

3.4. Контраст розмірів.

4. Технічність виконання.

Ми вважаємо, що графічний дизайн-колаж українських авторів як вид та прийом є невід'ємною складовою та впливовим елементом у формуванні графічного дизайну в концепції національної моделі дизайну України. Колаж поширюється як ініціатива та зацікавленість дизайнерів-практиків. Підгрунтя парадигми сучасного дизайну грунтується на синтезі трансцендентальних та аналітичних категорій, принципів і методів. Науковці стверджують, що сучасна парадигма дизайну спрямована прояснити первинність практичного досвіду автора, що онтологічно вкорінений в його свідомість та досвід. «До парадигми дизайну належить потенціал цілераціонального практичного досвіду людини і здатність репрезентації дизайнерської діяльності засобами цілераціональності задля самореалізації людини» [8, с. 114].

Базовим дослідженням щодо національної моделі дизайну України є дисертаційна робота В. Даниленка. 3 визначених вченим параметрів дизайну, що є сьогодні актуальними, ми звертаємо увагу на такі аспекти графічного дизайну:

1. «Властивість дизайну бути плюралістичною діяльністю в сфері створення утилітарних речей, яка передбачає множинність художньопроектних поглядів і як наслідок - урізноманітнений дизайнерський продукт аж до задоволення потреб конкретного індивіда.

2. Властивість дизайнерського твору бути наслідком дотепного, винахідливого, неординарного художньо-технічного рішення. 
3. Здатність дизайну бути проектною діяльністю, що поєднує в собі художнє та утилітарно-технічне начала» [4]. Автор наголошує, що в українській національній моделі пріоритет у тих проектів, де якомога активніше реалізовується художня складова дизайну, яка в Україні має високий ступінь розвитку.

Експерименти 3 сенсами, що $\epsilon$ основою колажних композицій, забезпечують варіативність змістовних повідомлень від дизайнера та інтерпретацій від адресата, що повністю забезпечує перший з визначених параметрів. Непередбачуваність експериментів 3 формою та сенсами створюють підгрунтя для оригінальності та неповторності дизайн-колажів, що цілком відповідає другому параметру. Третій 3 наведених параметрів пов'язаний зі своєрідною «картинністю» колажу, оскільки його історія починається зі сфери образотворчого мистецтва, а також колаж, сповнений художніми образами.

Важливим також $є$ твердження В. Даниленка про те, що «майбутнє українського дизайну полягає в формуванні національно орієнтованого світобачення» [4, с. 186]. Ця ідея грунтується на матеріалах наукових статей з етнодизайну. Введення до колажу, українських національно ідентифікованих елементів, забезпечують відповідну етнічну візуальність.

Водночас з раціональною спрямованістю в проектуванні, спостерігається суттєва потреба й графічних дизайнерів, і адресатів у емоційному компоненті, що так природно для української ментальності. Емоційність - ще одна складова концепції українського графічного дизайну. Кандидат мистецтвознавства і дизайнер-практик Н. Сбітнева звертає увагу на популярність у проектах останніх років рукотворних складових або їхнього імітування. Застосування рукотворних ефектів, заливок, фактур, мальованих графічних елементів, відбитків $\epsilon$ характерною ознакою високого рівня фаховості українських дизайнерів [9, с. 65]. Колаж, який в основі свого походження має аплікацію, тобто ручне поєднання різних елементів, навіть у своїй сучасній діджітл-формі апелює до практики рукотворності. Ми вважаємо, що сучасний електронний дизайн-колаж відповідає концепції імітації рукотворності, адже він апелює до пам'яті людей про те, що створювалося ручним засобом. Крім того, високоякісний колаж - це вид графічного дизайну, що в будь-якому випадку провокує емоції у глядача. Завдяки поєднанню різних елементів, застосуванню принципу «оксюморон» у візуалізації спектр емоцій може варіюватися від сміху й подиву до збентеження й навіть до відрази, але присутність емоцій при сприйнятті гарантована. Ну і нарешті, більшість рекламних, ілюстративних або плакатних колажів українських авторів містять елементи української ідентифікації, фрагменти витворів народної культури, які досить органічно вплетені в загальну композицію. Усі ці вищезазначені аспекти підтверджують, що графічний дизайн-колаж $\epsilon$ носієм i водночас чинником формування концепції сучасного українського графічного дизайну.

Таким чином, ознаками, за якими графічний дизайн-колаж визначається невід’ємною складовою національної моделі дизайну України, є: 
1. Ефект рукотворності

2. Емоційність

3. Багатозначність

4. Креативність

5. Візуальна ідентифікація графічними елементами етнічного походження

На основі аналізу робимо висновок, що графічний дизайн-колаж $є$ такою візуальною формою, що сприяє ефективному формуванню національної моделі графічного дизайну в Україні, а прийом колажування треба вивчати та вводити навчальним модулем у систему дизайн-освіти.

Студенти кафедри графічного дизайну КНУКіМ також долучені до вивчення естетики колажу. Серед випускників кафедри помітними $є$ проекти Ксенії Шляхтіної, яка вже у власній творчій практиці опановує стилістику мінімалізму в дизайн-колажі. А студенти першого курсу вивчають сутність та особливості прийомів колажу на дисципліні «Проектна графіка» під керівництвом автора цієї статті. Вивчення досвіду професійних дизайнерів та власні експерименти в колажах, створених ручним та електронним засобами, розкривають свободу мислення, нестандартність візуальних і змістовних поєднань. Колаж надає неосяжні можливості для розвитку креативності майбутніх графічних дизайнерів. Ми вважаємо, що для розвитку і художнього виховання фаховості студентів графічного дизайну колаж $є$ дуже ефективним засобом. У той час, колаж активує логіку та раціональність, адже колажист повинен вміти зібрати абсолютно несумісні між собою світлини в єдину збалансовану композицію, де використання кожного елементу обгрунтовано загальною змістовною та художньої концепцією твору.

Наукова новизна результатів дослідження полягає в уточненні поняття «колаж» та його особливостей в сфері графічного дизайну XXI ст. Зокрема, розглянуто поняття «діджитал-колаж», тобто колаж у проектах графічного дизайну, створений цифровим методом. Уточнено, що в українському варіанті це поняття має переклад як «цифровий» або «електронний» колаж. У статті також узагальнено історичні етапи формування культури колажу в графічному дизайні Європи та України. Розглянуто період формування колажу як виду образотворчого мистецтва (друге десятиріччя XX ст.); розвиток колажу в графічному дизайні школами дадаїстів, футуристів та конструктивістів (доба 1920-1930x pр.). Особливу увагу приділено українським кіноплакатам 19201930-х рр. та використанню фотоколажу в них. Це свідчить про те, що популярність колажу в сучасному українському графічному дизайні має свою історію та бере початок трохи менше 100 років тому. У статті зроблено огляд застосування колажу українськими графічними дизайнерами у рекламних кампаніях комерційних та культурних брендів, в оформленні книг та просто в мистецьких творах. Вперше сформульовано ознаки графічного дизайнколажу, які водночас $є$ і критеріями визначення рівня професійності того чи ін. проекту. Серед них експериментування з сенсами і значеннями (цитатність, абсурдність, асоціативність, фрагментарність), експериментування з візуальними 
формами і техніками (гротескність, стильова еклектика, фрагментарність, поєднання фотозображень, графічних елементів та акцидентних написів), динамічність композиції (порушення співвідношень реальних пропорцій зображених об'єктів, незвичність ракурсів, наявність візуальної домінанти, контраст розмірів), технічність виконання. Аналіз графічних дизайн-колажів співставлено 3 ознаками національної моделі дизайну в Україні, над формуванням якої працюють науковці та практики. Доведено, що завдяки таким ознакам, як ефект рукотворності, емоційність, багатозначність, креативність та візуальна ідентифікація графічними елементами етнічного походження характеризують його невід'ємною складовою, графічний дизайнколаж $\epsilon$ такою візуальною формою, що сприяє ефективному формуванню національної моделі графічного дизайну в Україні.

Висновки. Ми вважаємо, що сучасний графічний дизайн-колаж в Україні - це ефективний, 3 точки зору формування української моделі графічного дизайну, вид візуалізації ідей. Графічний дизайн-колаж фіксує в одному артефакті різні часи, минуле та сучасне, світлини як документальне свідчення життя та графіку як образне його узагальнення. Емоційність та деяка сентиментальність, що виникають через звернення до старовинних світлин, графічних елементів і фонових текстур, створюють у глядача позитивній настрій та здивування сміливості поєднань різноаспектних об'єктів і їхніх частин.

\section{Список використаних джерел}

1. Винникова Ю. Рауль Хаусман [Электронный ресурс] / Ю. Винникова Режим доступа: https://artifex.ru. - Загл. с экрана. - Дата обращения 01. 06. 2018.

2. Гладун О. Глобалізаційний і національний вектор розвитку графічного дизайну в Україні [Електронний ресурс] / О. Гладун - Режим доступу: http:// dspace.nbuv.gov.ua/bitstream/handle/123456789/16835/10-Gladun.pdf?sequence=1 . Назва з екрану. - Дата звернення 29.05.2018.

3. Гутник Л. Колекція українського радянського кіноплаката 1920-1930-х pp. [Електронний ресурс] / Л. Гутник - Режим доступу: http://www.nbuv. gov.ua/node/371 - Загл. с экрана. - Дата обращения 30.05.2018.

4. Даниленко В. Дизайн України у світовому контексті художньопроектної культури XX століття (національний та глобальний аспекти) : дис. докт. мистецтвознавства / В. Даниленко ; Львів. націон. акад. мистецтв. - Львів, 2006.

5. Колаж як вид декоративно-прикладної творчості / [Електронний pecypc] - Режим доступу: http://jak.magey.com.ua/articles/kolazh-jak-vid-dekora tivno-prikladnoi-tvorchosti.html - Загл. с экрана. - Дата обращения 30.05.2018.

6. Колісниченко Г. Колаж в образотворчому мистецтві: термінологія, класифікація та проблема вивчення / Г. Колісниченко // Вісн. Харк. держ. акад. дизайну і мистецтв. - Харків, 2011. - № 6. - С. 153-155. 
7. Педан І. Колаж в арт-дизайні: становлення та художні особливості / I. Педан // Вісн. Харк. держ. акад. дизайну і мистецтв. - Харків, 2015. - № 2. C. 44-49

8. Решетова М. Коллаж и перфоманс как стратегии размывания границ между традиционными практиками искусства / М. Решетова // Вест. Оренбург. гос. ун-та. - Оренбург, 2012. - №9(145). - С.65-69.

9. Рижова I. Наукові основи дизайну / I. Рижова // Гуманітар. вісн. Запорізької держ. інженерної академії. - Запоріжжя, 2015. - № 65. - С. 109-122

10. Сбітнєва Н. Тенденції розвитку сучасного графічного дизайну: повернення до рукотворності / Н. Сбітнєва // Вісн. Харк. держ. акад. дизайну і мистецтв. - Харків, 2015. - № 4. - С. 60-66.

11. Lusanne J. John Heartfield: Laughter Is A Devastating Weapon [Electronic resource] / J. Lusanne - Mode of access: https://www.wsws.org/en/articles/2015/ 12/28/hear-d28.html. - Title from the screen. - Last access 01 June 2018

\section{References}

1. Vinnikova, Yu. (2018). 'Raul Khausman'. Available at: <https://artifex.ru> [Accessed 03 June 2018].

2. Hladun, O. (2018). 'Globalization and national vector of development of graphic design in Ukraine'. Available at: <http://dspace.nbuv.gov.ua/bitstream/ handle/123456789/16835/10-Gladun.pdf?sequence=1> [Accessed 03 June 2018].

3. Hutnyk, L. (2018). 'Collection of Ukrainian Soviet Cinema Posters of 1920s-1930s'. Available at: <http://www.nbuv.gov.ua/node/371> [Accessed 03 June 2018]

4. Danylenko, V. (2006). Ukrainian Design in the World Context of Artistic and Design Culture of the Twentieth Century (National and Global Aspects.) D.Ed. Lviv National Academy of Arts.

5. 'Collage as a kind of decorative and applied art'. Available at: <http://jak.magey.com.ua/articles/kolazh-jak-vid-dekorativno-prikladnoitvorchosti.html> [Accessed 03 June 2018].

6. Kolisnychenko, H. (2011). Collage in fine arts: terminology, classification and the problem of studying. Visnyk Kharkivskoi derzhavnoi akademii dyzainu $i$ mystetstv [Bulletin of Kharkov State Academy of Design and Arts], no. 6, pp. 153155.

7. Pedan, I. (2015). Collage in art design: formation and artistic features. Visnyk Kharkivskoi derzhavnoi akademii dyzainu i mystetstv [Bulletin of Kharkov State Academy of Design and Arts], no 2, pp. 44-49.

8. Reshetova, M. (2012). Collage and performance as strategies for blurring the boundaries between traditional practices of art. Vestnik Orenburgskogo gosudarstvennogo universiteta [Bulletin of Orenburg State University], no. 9(145), pp.65-69.

9. Ryzhova, I. (2015) Scientific fundamentals of design. Humanitarnyi visnyk Zaporizkoi derzhavnoi inzhenernoi akademii [Humanitarian Bulletin of Zaporizhzhia State Engineering Academy], no. 65, pp. 109-122. 
10. Sbitnieva, N. (2015). Trends in the development of modern graphic design: the return to hand-made. Visnyk Kharkivskoi derzhavnoi akademii dyzainu i mystetstv [Bulletin of Kharkiv State Academy of Design and Arts], no. 4, pp. 60-66.

11. Lusanne J. 'John Heartfield: Laughter Is A Devastating Weapon'. Available at: <https://www.wsws.org/en/articles/2015/12/28/hear-d28.html>. - [Accessed 01 June 2018]

(C) Удріс-Бородавко Н. С., 2018 